\title{
Regulation of stem cell factor expression in inflammation and asthma
}

\author{
Carla A Da Silva, Nelly Frossard ${ }^{+}$ \\ Faculté de Pharmacie, Université Louis Pasteur, BP 24, 67401 Illkirch cedex, France
}

\begin{abstract}
Stem cell factor (SCF) is a major mast cell growth factor, which could be involved in the local increase of mast cell number in the asthmatic airways. In vivo, SCF expression increases in asthmatic patients and this is reversed after treatment with glucocorticoids. In vitro in human lung fibroblasts in culture, IL-1 $\beta$, a pro-inflammatory cytokine, confirms this increased SCF $m R N A$ and protein expression implying the MAP kinases p38 and ERK1/2 very early post-treatment, and glucocorticoids confirm this decrease. Surprisingly, glucocorticoids potentiate the IL-1 $\beta$-enhanced SCF expression at short term treatment, implying increased SCF mRNA stability and SCF gene transcription rate. This potentiation involves $p 38$ and ERK1/2. Transfection experiments with the SCF promoter including intronl also confirm this increase and decrease of SCF expression by $I L-1 \beta$ and glucocorticoids, and the potentiation by glucocorticoids of the IL-1 $\beta$-induced SCF expression. Deletion of the GRE or $K B$ sites abolishes this potentiation, and the effect of $I L-1 \beta$ or glucocorticoids alone. DNA binding of GR and NF- $K B$ are also demonstrated for these effects. In conclusion, this review concerns new mechanisms of regulation of SCF expression in inflammation that could lead to potential therapeutic strategy allowing to control mast cell number in the asthmatic airways.
\end{abstract}

Key words: stem cell factor - inflammation - asthma

The stem cell factor (SCF), also called Kit ligand, steel factor or mast cell growth factor (Huang et al. 1990, Martin et al. 1990, Zsebo et al. 1990), is the ligand of the product encoded by the proto-oncogene c-kit. SCF is expressed in two forms, soluble (sSCF) and membranebound $(\mathrm{mSCF})$ after alternative splicing of the sixth exon, which encodes a proteolytic cleavage site (Anderson et al. 1991, Flanagan et al. 1991). SCF is involved in the early phases of hematopoiesis (de Vries et al. 1991, Brandt et al. 1992) (for review, see Galli et al. 1994, Broudy 1997). In particular, this growth factor also acts as an important growth factor for human and murine mast cells (Galli et al. 1994, 1995, Broudy 1997), including in vitro proliferation and differentiation of immature $\mathrm{CD} 34^{+}$progenitors into mast cells in the bone marrow (Kirshenbaum et al. 1992), and in peripheral blood (Rottem et al. 1994, Welker et al. 2000).

SCF improves survival of mast cells by inhibiting their apoptosis (Mekori et al. 1993, Iemura et al. 1994). It induces their chemotaxis (Meininger et al. 1992, Nilsson et al. 1994), and plays a role in their adhesion to the extracellular matrix (Dastych \& Metcalfe 1994, Kinashi \& Springer 1994). In its membrane form, SCF acts as an adhesion molecule for them (Adachi et al. 1992, 1995, Kinashi \& Springer 1994). SCF induces mast cell hyperplasia in vivo after subcutaneous injection in humans (Costa et al. 1996, Dvorak et al. 1998). In vitro it increases the antigen-induced degranulation of human pulmonary mast cells (Bischoff \& Dahinden 1992, Okayama et al. 1994) and it-

\footnotetext{
${ }^{+}$Corresponding author.

E-mail: nelly.frossard@ pharma.u-strasbg.fr

Received 8 November 2004

Accepted 30 December 2004
}

self induces mast cell degranulation both in vitro (Columbo et al. 1992, Takaishi et al. 1994, Taylor et al. 1996a) and in vivo (Wershil et al. 1992, Costa et al. 1996). Mast cell number and activation are locally increased in chronic inflammatory diseases such as asthma (Lozewicz et al. 1988, Beasley et al. 1989, Djukanovic et al. 1990, Bradley et al. 1991, Ollerenshaw \& Woolcock 1992, Saetta et al. 1992, Pesci et al. 1993, Laitinen et al. 1993, Bradding et al. 1994, Koshino et al. 1996). Since SCF is the principal growth factor for mast cells, it might be expressed in human bronchi and regulated in airway structural cells in pro- and anti-inflammatory conditions. That is, increased SCF expression in the bronchi of a patient with asthma would be associated with increased number and activation of mast cells. On the other hand, glucocorticoid anti-inflammatory treatment of asthma may diminish SCF expression and thereby reduce the number of mast cells. The present review relates studies of the expression and regulation of SCF expression in asthma conditions in vivo and in vitro.

\section{SCF expression in asthma in vivo}

In vivo, $\mathrm{SCF}$ expression is regulated in the bronchi of asthmatic patients in both inflammatory and anti-inflammatory conditions, since this expression both increases and diminishes, respectively, together with the number of mast cells (Da Silva et al. 2004a). More particularly, two studies show that SCF expression in the bronchi is high in subjects with asthma, compared with healthy subjects (Da Silva et al. 2004a, Al-Muhsen et al. 2004). In addition, SCF expression is lower in glucocorticoid-treated subjects with asthma (Da Silva et al. 2004a).

At the same time, the mast cell number is increased in the bronchi of asthmatic patients, often as degranulated, and decreased in the bronchi of asthmatic patients treated with glucocorticoids, where they eventually reached normal levels. These findings of the mast cell signature confirmed previous data from the literature in glucocorticoid- 
treated asthmatics (Bradding et al. 1994, Koshino et al. 1996, Djukanovic et al. 1997, Olivieri et al. 1997).

Thus SCF, released by airway structural cells (Da Silva et al. 2002, 2003, 2004b, Kassel et al. 1998, 1999) could play some role in increasing the number and/or activation of mast cells in the human airways, and glucocorticoids may decrease mast cell number and activation at least in part through decreased SCF expression. Similar effects in human skin are suggested by work showing that glucocorticoids reduce the number of mast cells and the SCF expression (Finotto et al. 1997).

SCF expression in the bronchi and the number of mast cells are regulated in pro- and anti-inflammatory conditions, but the mechanisms for this regulation are not yet known. This regulation of SCF expression has been studied in human airway cells in vitro to help understand how targeting SCF expression may help to treat asthma.

\section{SCF expression in pro- and anti-inflammatory conditions in vitro}

Effect of IL-1 $\beta$ on SCF gene transcription - Interleukin (IL)-1ß, one of the major pro-inflammatory cytokine present within the asthmatic airways, increases the expression of SCF mRNA and SCF protein as a function of time (0 to $2.5 \mathrm{~h}$ ), without modifying the relative expression of the two forms, SSCF and mSCF, at $30 \mathrm{~min}$ (Da Silva et al. 2004b). Studying the effect of inhibitors of the three mitogenactivated protein (MAP) kinase pathways showed that the MAP kinases p38 and extracellular signal regulated kinase (ERK) $1 / 2$ each accounted for $50 \%$ of the augmentation of SCF mRNA by IL-1B at 30 min, while the Jun kinase pathway had no role in this effect (Da Silva et al. 2003). Chromatin immunoprecipitation experiments proved further that the transcription factor nuclear factor (NF)$\kappa \mathrm{B}$ binds at 30 min to a $\mathrm{\kappa B}$ responsive element consensus sequence identified in the first intron of the SCF promoter gene (Da Silva et al. 2003). Deletion of this responsive element as well as pre-treatment with pyrrolidine dithiocarbamate (PDTC), a NF- $\mathrm{kB}$ inhibitor, shows that at $30 \mathrm{~min}$ $\mathrm{NF}-\mathrm{KB}$ is the only transcription factor necessary for the early IL-1ß-induced increase in SCF expression (Da Silva et al. 2003, 2004b).

Although other studies show that IL-1ß slightly increases SCF expression by structural cells at $24 \mathrm{~h}$ (Aye et al. 1992, Linenberger et al. 1995), less is known about the mechanisms involved in these effects. Interestingly, Da Silva et al. (2002) showed that SCF mRNA expression induced by IL- $1 \beta$ peaked at $2.5 \mathrm{~h}$ and that it returned to normal levels within $24 \mathrm{~h}$ (unpublished observations). IL$1 B$ is known to stimulate the MAP kinase pathways within minutes (Lian et al. 1999), thereby stimulating such transcription factors as NF- KB (Janssen-Heininger et al. 1999, Liang \& Gardner, 1999). The originality of the results by Da Silva et al. (2003) lies in the finding that a single transcription factor, located originally on an intron, transmits the effects of IL-1ß early (30 min) during this regulation of SCF expression (Da Silva et al. 2003). It is not yet clear if this remains true at later periods. Indeed, other responsive elements are present in the SCF gene promoter, in particular AP-1 or CREB (Taylor et al. 1996b), that might influence the effects of IL-1ß over a longer term, since reports show both of these transcription factors mediate effects of IL-1B (Laporte et al. 2000, Song et al. 2003).

SCF expression is thus increased in vitro by inflammatory conditions, as are other inflammatory mediators involved in asthma, such as eotaxin, the monocyte chemoattractant protein (MCP)-4 (Lamkhioued et al. 2000, Sato et al. 2001), and various interleukins. Accordingly, the inflammatory conditions created in vitro by IL- $1 \beta$ treatment, which is responsible for the increase in SCF production, are consistent with the conditions that induce elevated SCF expression in vivo in the bronchi of subjects with asthma (Da Silva et al. 2004a, Al-Muhsen et al. 2004), associated with an elevated number and activation status of the mast cells in the airways (Da Silva et al. 2004a).

Glucocorticoids and SCF gene transcription - Glucocorticoids, such as budesonide and dexamethasone, have been shown to diminish constitutive expression of SCF mRNA and SCF protein as a function of time (0 to $2.5 \mathrm{~h}$ ), without modifying the relative expression of the two forms of SCF, sSCF and mSCF at $30 \mathrm{~min}$ (Da Silva et al. 2004b). This reduction was not modified by inhibitors of the three MAP kinase pathways, thereby confirming findings from the literature (Da Silva et al. 2003). These authors showed additionally by chromatin immunoprecipitation experiments that the glucocorticoid receptor (GR) complex binds to a GRE-like (glucocorticoid responsive element) sequence previously described in the SCF promoter (Taylor et al. 1996b, Da Silva et al. 2003, 2004b). Furthermore, transfection experiments with deletion of the GRE-like sequence and pre-treatment by RU486, the glucocorticoid receptor antagonist, showed that at short term (30 min) the effects of glucocorticoids on SCF expression are receptor-dependent.

This inhibitory effect by glucocorticoids is consistent with the diminution in constitutive expression of SCF mRNA and protein at $2.5 \mathrm{~h}$, previously observed (Kassel et al. 1998). The kinetics of the glucocorticoid-induced diminution in mRNA expression peaked at $2.5 \mathrm{~h}$ (Kassel et al. 1998, Da Silva et al. 2004b). Moreover, in a short time (30 min), the GR complex inhibited SCF expression by binding to GRE (Da Silva et al. 2003), which has been described as a transactivator element. The GRE sequence may overlap the sequence of another transcription factor, one involved in inhibiting basal SCF expression, but no responsive element corresponding to this hypothesis has so far been identified in the SCF promoter (Taylor et al. 1996b). Experiments with protein co-immunoprecipitation or chromatin immunoprecipitation might show whether GR is capable of interacting with other transcription factors, such as CREB or AP-1, which may, according to Taylor et al. (1996b), play a role in basal SCF expression.

Glucocorticoids and IL-1ß-induced SCF gene transcription - The glucocorticoids, budesonide and dexamethasone, have been reported as surprisingly potentiating the IL-1B-induced expression of SCF mRNA and protein at 30 min without modifying the relative expression of the two forms of SCF (30 min, Da Silva et al. 2004b). The effects of the three MAP kinase pathway inhibitors showed that p38 and ERK1/2 each accounted for 50\% of this IL$1 \beta$-induced potentiation of SCF mRNA at $30 \mathrm{~min}$, while 
the Jun kinase pathway had no role then (Da Silva et al. 2003). This potentiation of SCF expression by the association of IL-1ß and glucocorticoids at $30 \mathrm{~min}$ is related to increased SCF gene transcription (Da Silva et al. 2004b), which in turn depends on the binding of NF- $\mathrm{KB}$ and of activated GR to their respective responsive elements (Da Silva et al. 2003). Moreover, the deletion of either of these responsive elements, or effect of the NF-KB inhibitor, PDTC, or of RU486 showed abolition of this potentiation, the induction of which therefore depends on an interaction between GR and NF- $\kappa B$ (Da Silva et al. 2003, 2004b).

Very few studies in the literature report such synergy between the IL-1ß and glucocorticoid pathways or between NF- $\kappa B$ and GR. It has already been described for the cellular-inhibitors of apoptosis proteins, c-IAPs, for which NF- $\mathrm{KB}$ and dexamethasone have additive transactivator effects at $2 \mathrm{~h}$, which are still greater at $24 \mathrm{~h}$ (Webster et al. 2002). No proposals so far attempt to explain the mechanisms involved in these effects. Altogether, these results suggest that a factor with co-activating properties may interact directly with NF- $\mathrm{KB}$ and GR (Da Silva et al. 2003). This factor must still be identified. For now, however, the direct interactions between NF- $\mathrm{KB}$ and GR have involved only a diminution in gene expression and not its stimulation or potentiation (Adcock 2001). For this rea- son, the hypothesis can be raised that factors may be needed to activate the bond between NF-KB and GR to potentiate SCF expression (Figure). The general transcription co-activator c-AMP binding protein (CBP) or the coactivator of the glucocorticoid receptor SRC (steroid receptor co-activator) might play a role in this effect.

It is only after an hour of treatment that the expected diminution by budesonide of the IL-1B-induced SCF expression is observed. Glucocorticoids are well known to inhibit the expression of mediators involved in inflammation, in particular, NF- $\mathrm{kB}$. Many mechanisms for this inhibition of NF- $\mathrm{KB}$ by glucocorticoids have been proposed (for review, see Cato \& Wade 1996). After the accumulation of GR in the cell, a protein-protein interaction may take place between NF- $\kappa$ B and GR (McKay \& Cidlowski 1998) and prevent either the binding of NF- $\mathrm{\kappa B}$ to its responsive element, or the transactivator effect of NF- $\mathrm{kB}$ associated with its responsive element (Nissen \& Yamamoto 2000). Another possibility is the inhibition of the MAP kinase pathways by glucocorticoids, as suggested by the work of Kassel et al. (2001), who found that glucocorticoids induce the expression and activation of the MAP kinase phosphatase (MKP)-1. Additional experiments should confirm whether glucocorticoids inhibit the transactivator effect of NF-KB on SCF expression after

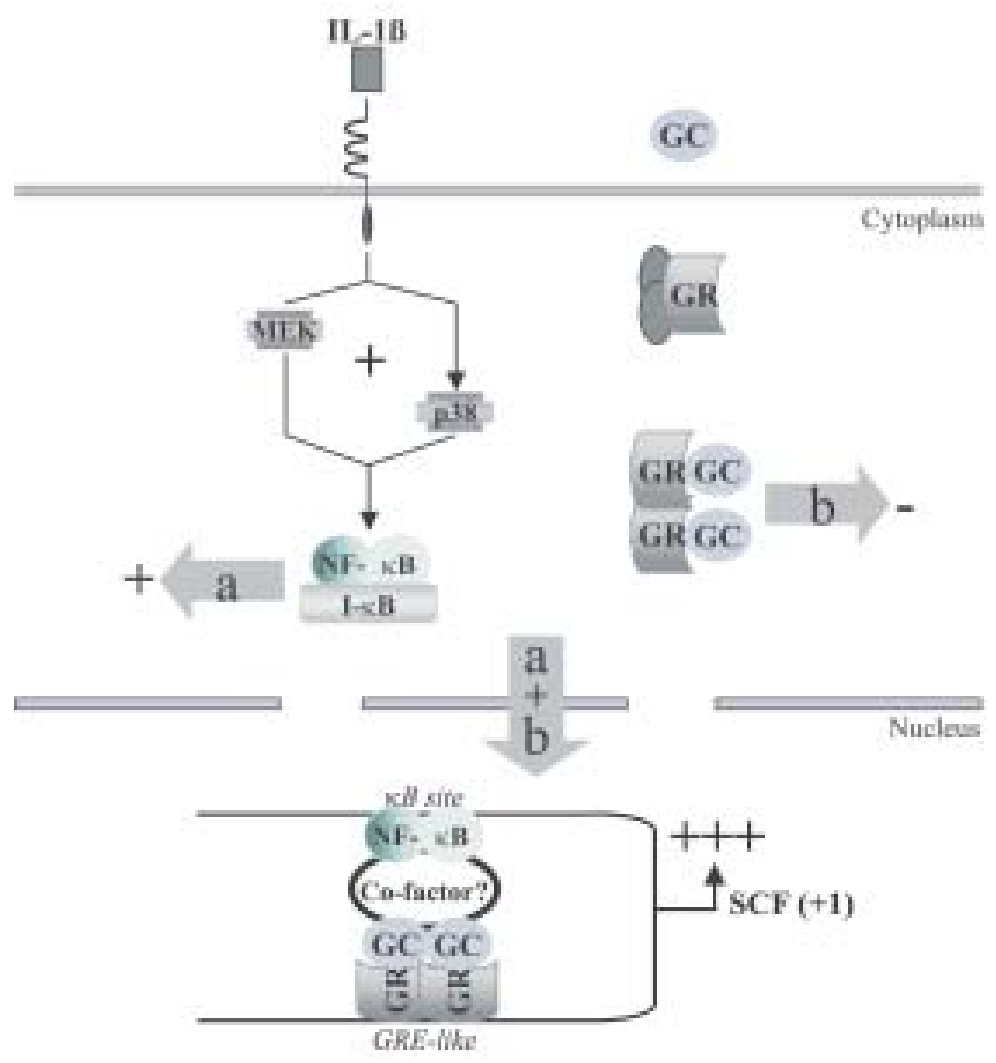

A proposed mechanism involved in the stem cell factor (SCF) gene regulation by interleukin-1ß (IL-1ß) and budesonide. a: IL-1ß stimulates mitogen-activated protein MAP kinases after binding to its receptor, leading to the activation of the transcription nuclear factor $\mathrm{kB}$ (NF$\kappa B)$. Activated NF- $\kappa B$ translocates into the nucleus, binds to the $\kappa B$ site present in the first intron of the SCF gene and induces SCF gene transcription; b: the glucocorticoid (GC) diffuses into the cell cytoplasm and binds to the glucocorticoid receptor (GR). The activated complex translocates into the nucleus and binds the GC responsive element-like present in the SCF promoter to inhibit SCF gene transcription; $\mathrm{a}+\mathrm{b}$ : the hypothesis resides in the requirement of a common co-factor by the combination of IL-1ß and budesonide to induce potentiation of the SCF gene transcription. 
$1 \mathrm{~h}$, or if they inhibit the binding of other transcription factors, such as AP-1 (Diamond et al. 1990), to their responsive elements and the induction of their transactivator effects.

In any case, the diminution by glucocorticoids of SCF expression in inflammatory conditions is consistent with the diminution of SCF expression reported in vivo, in subjects with asthma treated with glucocorticoids (Da Silva et al. 2004a). This is also true for other inflammatory mediators involved in asthma, such as MCP-4 (Lamkhioued et al. 2000). This diminution of SCF expression by glucocorticoids may contribute to the reduction in the number and activation status of mast cells in the airways of subjects with asthma after glucocorticoid treatment.

SCF mRNA stability - Glucocorticoids and IL-1B increase the stability of SCF mRNA very early (30 min), while neither IL-1ß nor glucocorticoids alone have any effect on this stability at such short term (Da Silva et al. 2004b). This stability is decreased by the association between IL$1 \beta$ and the glucocorticoids at $2.5 \mathrm{~h}$, a time point at which IL-1 1 alone increases SCF mRNA stability and where glucocorticoids alone diminish it (Kassel et al. 1998, Da Silva et al. 2002). Finally, the combination of glucocorticoids and IL- $1 B$ also diminish the stability of SCF mRNA at $10 \mathrm{~h}$, while neither IL-1ß nor glucocorticoids alone have any effect on this stability (Da Silva et al. 2002). The effect of IL-1ß alone on the increased stability of mRNAs has been described for cyclo-oxygenase (COX)-2 mRNA (Ridley et al. 1998). Glucocorticoids are also known to destabilize iNOS mRNA, whereas an increased stability of iNOS mRNA is reported at $15 \mathrm{~h}$ to be an effect of IL-1B combined with dexamethasone (Kunz et al. 1996). Nonetheless, the signaling pathways leading to either stabilization or destabilization are not known. The presence of key sequences, the AURE (AU-rich responsive element) sequences in the 3 ' region of mRNA, generally determines whether IL-1ß and glucocorticoids stabilize or destabilize mRNA. SCF mRNA does not have an AURE sequence (Martin et al. 1990), however. This suggests that the mechanisms by which IL- $1 \beta$ and glucocorticoids stabilize or destabilize SCF mRNA are still unknown. These mechanisms may involve regulation of the poly $\left(\mathrm{A}^{+}\right)$binding proteins to the mRNA (PABP) or of the polyadenylation process for mRNA, which would stabilize it (Stoeckle 1992, Ross 1995).

Relative SCF expression - At short term treatment (30 $\mathrm{min}$ ), the relative expression of the two forms of SCF, sSCF and $\mathrm{mSCF}$, is not modified by IL-1ß, glucocorticoids or their combination. It is known that the relative expression of sSCF and $\mathrm{mSCF}$ varies in vitro according to cell type (Kassel et al. 1999) and that both forms can be involved in the augmentation of the number and/or activation of mast cells. Membrane-bound SCF, for example, may play a more important role than $\mathrm{SSCF}$ in the in vivo development of mast cells, as suggested by work in mutant mice homozygous for the Steel Dickie (Sld) allele: they produce biologically active SSCF but not $\mathrm{mSCF}$ and suffer from a profound mast cell deficiency (Brannan et al. 1991). mSCF also stimulates the development of hematopoietic cells still more than SSCF (Toksoz et al. 1992). A possible explanation is that the mSCF stimulation of the
Kit receptor delays internalization of the SCF-Kit complex and accordingly delays the end of the stimulation (Miyazawa et al. 1991, Toksoz et al. 1992). Moreover, mSCF acts as an adhesion molecule for mast cells (Kinashi et al. 1994, Adachi et al. 1995). The relative expression of the two forms of SCF should be verified in patients with asthma who are and are not treated with glucocorticoids and compared with results in healthy subjects to see if expression of these two forms varies in vivo in humans during the disease.

\section{Conclusion}

In conclusion, SCF expression increases in pro-inflammatory conditions and diminishes in anti-inflammatory conditions in vitro. These findings confirm results obtained in vivo in patients with asthma. Glucocorticoids are also shown to have unexpected effects in the regulation of SCF gene at very short treatment times $(30 \mathrm{~min})$, since SCF expression is potentiated by glucocorticoids in pro-inflammatory conditions. The mechanisms involved in this effect are only partially elucidated. The hypothesis of the existence of a co-activator linking NF- $\mathrm{\kappa B}$ and GR in the potentiation of SCF expression still needs to be confirmed. Once confirmed and identified, this co-activator might become a treatment target for inhibiting the harmful effect of SCF in disease. The physiological role of SCF in the airways and its role in asthma also require further elucidation. Altogether, SCF may be proposed as an interesting target for asthma treatment through its effect on the regulation of the number and activation status of mast cells, those inflammatory cells for which it is one of the most important growth factors.

\section{REFERENCES}

Adachi S, Ebi Y, Nishikawa S, Hayashi S, Yamazaki M, Kasugai T, Yamamura T, Nomura S, Kitamura Y 1992. Necessity of extracellular domain of $\mathrm{W}$ (c-kit) receptors for attachment of murine cultured mast cells to fibroblasts. Blood 79: 650656.

Adachi S, Tsujimura T, Jippo T, Morimoto M, Isozaki K, Kasugai T, Nomura S, Kitamura Y 1995. Inhibition of attachment between cultured mast cells and fibroblasts by phorbol 12-myristate 13-acetate and stem cell factor. Exp Hematol 23: 58-65.

Adcock IM 2001. Glucocorticoid-regulated transcription factors. Pulm Pharmacol Ther 14: 211-219.

Al-Muhsen SZ, Shablovsky G, Olivenstein R, Mazer B, Hamid Q 2004. The expression of stem cell factor and c-kit receptor in human asthmatic airways. Clin Exp Allergy 34: 911916.

Anderson DM, Williams DE, Tushinski R, Gimpel S, Eisenman J, Cannizzaro LA, Aronson M, Croce CM, Huebner K, Cosman D, Lyman SD 1991. Alternate splicing of mRNAs encoding human mast cell growth factor and localization of the gene to chromosome 12q22-q24. Cell Growth Differ 2: 373-378.

Aye MT, Hashemi S, Leclair B, Zeibdawi A, Trudel E, Halpenny M, Fuller V, Cheng G 1992. Expression of stem cell factor and c-kit mRNA in cultured endothelial cells, monocytes and cloned human bone marrow stromal cells (CFU-RF). Exp Hematol 20: 523-527. 
Beasley R, Roche WR, Roberts JA, Holgate ST 1989. Cellular events in the bronchi in mild asthma and after bronchial provocation. Am Rev Respir Dis 139: 806-817.

Bischoff SC, Dahinden CA 1992. c-kit ligand: a unique potentiator of mediator release by human lung mast cells. J Exp Med 175: 237-244.

Bradding P, Roberts JA, Britten KM, Montefort S, Djukanovic R, Mueller R, Heusser CH, Howarth PH, Holgate ST 1994. Interleukin-4, -5 , and -6 and tumor necrosis factor-alpha in normal and asthmatic airways: evidence for the human mast cell as a source of these cytokines. Am J Respir Cell Mol Biol 10: 471-480.

Bradley BL, Azzawi M, Jacobson M, Assoufi B, Collins JV, Irani AM, Schwartz LB, Durham SR, Jeffery PK, Kay AB 1991. Eosinophils, T-lymphocytes, mast cells, neutrophils, and macrophages in bronchial biopsy specimens from atopic subjects with asthma: comparison with biopsy specimens from atopic subjects without asthma and normal control subjects and relationship to bronchial hyperresponsiveness. J Allergy Clin Immunol 88: 661-674.

Brandt J, Briddell RA, Srour EF, Leemhuis TB, Hoffman R 1992. Role of c-kit ligand in the expansion of human hematopoietic progenitor cells. Blood 79: 634-641.

Brannan CI, Lyman SD, Williams DE, Eisenman J, Anderson DM, Cosman D, Bedell MA, Jenkins NA, Copeland NG 1991. Steel-Dickie mutation encodes a c-kit ligand lacking transmembrane and cytoplasmic domains. Proc Natl Acad Sci USA 88: 4671-4674.

Broudy VC 1997. Stem cell factor and hematopoiesis. Blood 90: 1345-1364.

Cato AC, Wade E 1996. Molecular mechanisms of anti-inflammatory action of glucocorticoids. Bioessays 18: 371-378.

Columbo M, Horowitz EM, Botana LM, MacGlashan Jr DW, Bochner BS, Gillis S, Zsebo KM, Galli SJ, Lichtenstein LM 1992. The human recombinant c-kit receptor ligand, rhSCF, induces mediator release from human cutaneous mast cells and enhances IgE-dependent mediator release from both skin mast cells and peripheral blood basophils. J Immunol 149: 599-608.

Costa JJ, Demetri GD, Harrist TJ, Dvorak AM, Hayes DF, Merica EA, Menchaca DM, Gringeri AJ, Schwartz LB, Galli SJ 1996. Recombinant human stem cell factor (kit ligand) promotes human mast cell and melanocyte hyperplasia and functional activation in vivo. J Exp Med 183: 2681-2686.

Da Silva CA, De Blay F, Israel-Biet D, Laval A-M, Glasser N, Pauli G, Frossard N 2004a. Stem cell factor (SCF) expression in human asthmatic bronchi treated or not by glucocorticoids.

Da Silva CA, Heilbock C, Kassel O, Frossard N 2003. Transcription of stem cell factor (SCF) is potentiated by glucocorticoids and interleukin-1 beta through concerted regulation of a GRE-like and an NF-kappaB response element. FASEB J 17: 2334-2336 and e-pub 16 Oct 2003.

Da Silva CA, Kassel O, Lebouquin R, Lacroix EJ, Frossard N, Heilbock C 2004b. Paradoxical early glucocorticoid induction of stem cell factor (SCF) expression in inflammatory conditions. Br J Pharmacol 141: 75-84.

Da Silva CA, Kassel O, Mathieu E, Massard G, Gasser B,
Frossard N 2002. Inhibition by glucocorticoids of the interleukin-1beta-enhanced expression of the mast cell growth factor SCF. Br J Pharmacol 135: 1634-1640.

Dastych J, Metcalfe DD 1994. Stem cell factor induces mast cell adhesion to fibronectin. J Immunol 152: 213-219.

de Vries P, Brasel KA, Eisenman JR, Alpert AR, Williams DE 1991). The effect of recombinant mast cell growth factor on purified murine hematopoietic stem cells. J Exp Med 173: 1205-1211.

Diamond MI, Miner JN, Yoshinaga SK, Yamamoto KR 1990. Transcription factor interactions: selectors of positive or negative regulation from a single DNA element. Science 249: 1266-1272.

Djukanovic R, Homeyard S, Gratziou C, Madden J, Walls A, Montefort S, Peroni D, Polosa R, Holgate S, Howarth P 1997. The effect of treatment with oral corticosteroids on asthma symptoms and airway inflammation. Am J Respir Crit Care Med 155: 826-832.

Djukanovic R, Wilson JW, Britten KM, Wilson SJ, Walls AF, Roche WR, Howarth PH, Holgate ST 1990. Quantitation of mast cells and eosinophils in the bronchial mucosa of symptomatic atopic asthmatics and healthy control subjects using immunohistochemistry. Am Rev Respir Dis 142: 863-871.

Dvorak AM, Costa JJ, Monahan-Earley RA, Fox P, Galli SJ 1998. Ultrastructural analysis of human skin biopsy specimens from patients receiving recombinant human stem cell factor: subcutaneous injection of rhSCF induces dermal mast cell degranulation and granulocyte recruitment at the injection site. J Allergy Clin Immunol 101: 793-806.

Finotto S, Mekori YA, Metcalfe DD 1997. Glucocorticoids decrease tissue mast cell number by reducing the production of the c-kit ligand, stem cell factor, by resident cells: in vitro and in vivo evidence in murine systems. J Clin Invest 99: 1721-1728.

Flanagan JG, Chan DC, Leder P 1991. Transmembrane form of the kit ligand growth factor is determined by alternative splicing and is missing in the Sld mutant. Cell 64: 10251035.

Galli SJ 1990. New insights into "the riddle of the mast cells": microenvironmental regulation of mast cell development and phenotypic heterogeneity. Lab Invest 62: 5-33.

Galli SJ, Tsai M, Wershil BK, Tam SY, Costa JJ 1995. Regulation of mouse and human mast cell development, survival and function by stem cell factor, the ligand for the c-kit receptor. Int Arch Allergy Immunol 107: 51-53.

Galli SJ, Zsebo KM, Geissler EN 1994. The kit ligand, stem cell factor. Adv Immunol 55: 1-96.

Huang E, Nocka K, Beier DR, Chu TY, Buck J, Lahm HW, Wellner D, Leder P, Besmer P 1990. The hematopoietic growth factor KL is encoded by the Sl locus and is the ligand of the c-kit receptor, the gene product of the $\mathrm{W}$ locus. Cell 63: 225-233.

Iemura A, Tsai M, Ando A, Wershil BK, Galli SJ 1994. The ckit ligand, stem cell factor, promotes mast cell survival by suppressing apoptosis. Am J Pathol 144: 321-328.

Janssen-Heininger YM, Macara I, Mossman BT 1999. Cooperativity between oxidants and tumor necrosis factor in the activation of nuclear factor (NF)-kappaB: require- 
ment of Ras/mitogen-activated protein kinases in the activation of NF-kappaB by oxidants. Am J Respir Cell Mol Biol 20: 942-952.

Kassel O, Sancono A, Kratzschmar J, Kreft B, Stassen M, Cato AC 2001. Glucocorticoids inhibit MAP kinase via increased expression and decreased degradation of MKP-1. Embo J 20: 7108-7116.

Kassel O, Schmidlin F, Duvernelle C, de Blay F, Frossard N 1998. Up- and down-regulation by glucocorticoids of the constitutive expression of the mast cell growth factor stem cell factor by human lung fibroblasts in culture. $\mathrm{Mol}$ Pharmacol 54: 1073-1079.

Kassel O, Schmidlin F, Duvernelle C, Gasser B, Massard G, Frossard N 1999. Human bronchial smooth muscle cells in culture produce stem cell factor. Eur Respir J 13: 951-954.

Kinashi T, Springer TA 1994. Steel factor and c-kit regulate cellmatrix adhesion. Blood 83: 1033-1038.

Kirshenbaum AS, Goff JP, Kessler SW, Mican JM, Zsebo KM, Metcalfe DD 1992. Effect of IL-3 and stem cell factor on the appearance of human basophils and mast cells from CD34+ pluripotent progenitor cells. J Immunol 148: 772777.

Koshino T, Arai Y, Miyamoto Y, Sano Y, Itami M, Teshima S, Hirai K, Takaishi T, Ito K, Morita Y 1996. Airway basophil and mast cell density in patients with bronchial asthma: relationship to bronchial hyperresponsiveness. J Asthma 33: 89-95.

Kunz D, Walker G, Eberhardt W, Pfeilschifter J 1996. Molecular mechanisms of dexamethasone inhibition of nitric oxide synthase expression in interleukin 1 beta-stimulated mesangial cells: evidence for the involvement of transcriptional and posttranscriptional regulation. Proc Natl Acad Sci USA 93: 255-259.

Laitinen LA, Laitinen A, Haahtela T 1993. Airway mucosal inflammation even in patients with newly diagnosed asthma. Am Rev Respir Dis 147: 697-704.

Lamkhioued B, Garcia-Zepeda EA, Abi-Younes S, Nakamura H, Jedrzkiewicz S, Wagner L, Renzi PM, Allakhverdi Z, Lilly C, Hamid Q, Luster AD 2000. Monocyte chemoattractant protein (MCP)-4 expression in the airways of patients with asthma. Induction in epithelial cells and mononuclear cells by proinflammatory cytokines. Am J Respir Crit Care Med 162: 723-732.

Laporte JD, Moore PE, Lahiri T, Schwartzman IN, Panettieri Jr RA, Shore SA 2000. p38 MAP kinase regulates IL-1 beta responses in cultured airway smooth muscle cells. Am J Physiol Lung Cell Mol Physiol 279: L932-41.

Lian JP, Huang R, Robinson D, Badwey JA 1999. Activation of p90RSK and cAMP response element binding protein in stimulated neutrophils: novel effects of the pyridinyl imidazole SB 203580 on activation of the extracellular signalregulated kinase cascade. J Immunol 163: 4527-4536.

Liang F, Gardner DG 1999. Mechanical strain activates BNP gene transcription through a p38/NF-kappaB-dependent mechanism. J Clin Invest 104: 1603-1612.

Linenberger ML, Jacobson FW, Bennett LG, Broudy VC, Martin FH, Abkowitz JL 1995. Stem cell factor production by human marrow stromal fibroblasts. Exp Hematol 23: 11041114.
Lozewicz S, Gomez E, Ferguson H, Davies RJ 1988. Inflammatory cells in the airways in mild asthma. BMJ 297: 15151516.

Martin FH, Suggs SV, Langley KE, Lu HS, Ting J, Okino KH, Morris CF, McNiece IK, Jacobsen FW, Mendiaz EA, Birkett NC, Smith KA, Johnson MJ, Parker VP, Flores JC, Patel AC, Fisher EF, Erjavec HO, Herrera CJ, Wypych J, Sachdev RJ, Pope JA, Leslie A, Wen D, Lin CH, Cupples RL, Zsebo KM 1990. Primary structure and functional expression of rat and human stem cell factor DNAs. Cell 63: 203-211.

McKay LI, Cidlowski JA 1998. Cross-talk between nuclear factor-kappa B and the steroid hormone receptors: mechanisms of mutual antagonism. Mol Endocrinol 12: 45-56.

Meininger CJ, Yano H, Rottapel R, Bernstein A, Zsebo KM, Zetter BR 1992. The c-kit receptor ligand functions as a mast cell chemoattractant. Blood 79: 958-63.

Mekori YA, Oh CK, Metcalfe DD 1993. IL-3-dependent murine mast cells undergo apoptosis on removal of IL-3. Prevention of apoptosis by c-kit ligand. J Immunol 151: 3775 3784 .

Miyazawa K, Hendrie PC, Mantel C, Wood K, Ashman LK, Broxmeyer HE 1991. Comparative analysis of signaling pathways between mast cell growth factor (c-kit ligand) and granulocyte-macrophage colony-stimulating factor in a human factor-dependent myeloid cell line involves phosphorylation of Raf-1, GTPase-activating protein and mitogen- activated protein kinase. Exp Hematol 19: 1110-1123.

Nilsson G, Butterfield JH, Nilsson K, Siegbahn A 1994. Stem cell factor is a chemotactic factor for human mast cells. $J$ Immunol 153: 3717-3723.

Nissen RM, Yamamoto KR 2000. The glucocorticoid receptor inhibits NFkappaB by interfering with serine- 2 phosphorylation of the RNA polymerase II carboxy-terminal domain. Genes Dev 14: 2314-2329.

Okayama Y, Hunt TC, Kassel O, Ashman LK, Church MK 1994. Assessment of the anti-c-kit monoclonal antibody YB5.B8 in affinity magnetic enrichment of human lung mast cells. J Immunol Methods 169: 153-161.

Olivieri D, Chetta A, Del Donno M, Bertorelli G, Casalini A, Pesci A, Testi R, Foresi A 1997. Effect of short-term treatment with low-dose inhaled fluticasone propionate on airway inflammation and remodeling in mild asthma: a placebo-controlled study. Am J Respir Crit Care Med 155: 1864-1871.

Ollerenshaw SL, Woolcock AJ 1992. Characteristics of the inflammation in biopsies from large airways of subjects with asthma and subjects with chronic airflow limitation. Am Rev Respir Dis 145: 922-927.

Pesci A, Foresi A, Bertorelli G, Chetta A, Oliveri D 1993. Histochemical characteristics and degranulation of mast cells in epithelium and lamina propria of bronchial biopsies from asthmatic and normal subjects. Am Rev Respir Dis 147: 684-689.

Ridley SH, Dean JL, Sarsfield SJ, Brook M, Clark AR, Saklatvala J 1998. A p38 MAP kinase inhibitor regulates stability of interleukin-1-induced cyclooxygenase-2 mRNA. FEBS Lett 439: 75-80.

Ross J 1995. mRNA stability in mammalian cells. Microbiol Rev 59 423-450. 
Rottem M, Okada T, Goff JP, Metcalfe DD 1994. Mast cells cultured from the peripheral blood of normal donors and patients with mastocytosis originate from a CD34+/Fc epsilon RI- cell population. Blood 84: 2489-2496.

Saetta M, Di Stefano A, Maestrelli P, De Marzo N, Milani GF, Pivirotto F, Mapp CE, Fabbri LM 1992. Airway mucosal inflammation in occupational asthma induced by toluene diisocyanate. Am Rev Respir Dis 145: 160-168.

Sato E, Nelson DK, Koyama S, Hoyt JC, Robbins RA 2001. Inflammatory cytokines modulate eotaxin release by human lung fibroblast cell line. Exp Lung Res 27: 173-183.

Song KS, Seong JK, Chung KC, Lee WJ, Kim CH, Cho KN, Kang CD, Koo JS, Yoon JH 2003. Induction of MUC8 gene expression by interleukin-1 beta is mediated by a sequential ERK MAPK/RSK1/CREB cascade pathway in human airway epithelial cells. J Biol Chem 278: 34890-34896.

Stoeckle MY 1992. Removal of a 3' non-coding sequence is an initial step in degradation of gro alpha mRNA and is regulated by interleukin-1. Nucleic Acids Res 20: 1123-1127.

Takaishi T, Morita Y, Hirai K, Yamaguchi M, Ohta K, Noda E, Morita T, Ito K, Miyamoto T 1994. Effect of cytokines on mediator release from human dispersed lung mast cells. $A l$ lergy 49: 837-842.

Taylor AM, Galli SJ, Coleman JW 1996a. Dexamethasone or cyclosporin A inhibits stem cell factor-dependent secretory responses of rat peritoneal mast cells in vitro. Immunopharmacology 34: 63-70.

Taylor WE, Najmabadi H, Strathearn M, Jou NT, Liebling M, Rajavashisth T, Chanani N, Phung L, Bhasin S 1996b. Hu- man stem cell factor promoter deoxyribonucleic acid sequence and regulation by cyclic 3',5'-adenosine monophosphate in a Sertoli cell line. Endocrinology 137: 5407-5414.

Toksoz D, Zsebo KM, Smith KA, Hu S, Brankow D, Suggs SV, Martin FH, Williams DA 1992. Support of human hematopoiesis in long-term bone marrow cultures by murine stromal cells selectively expressing the membrane-bound and secreted forms of the human homolog of the steel gene product, stem cell factor. Proc Natl Acad Sci USA 89: 73507354.

Webster JC, Huber RM, Hanson RL, Collier PM, Haws TF, Mills JK, Burn TC, Allegretto EA 2002. Dexamethasone and tumor necrosis factor-alpha act together to induce the cellular inhibitor of apoptosis-2 gene and prevent apoptosis in a variety of cell types. Endocrinology 143: 3866-3874.

Welker P, Grabbe J, Zuberbier T, Guhl S, Henz BM 2000. Mast cell and myeloid marker expression during early in vitro mast cell differentiation from human peripheral blood mononuclear cells. J Invest Dermatol 114: 44-50.

Wershil BK, Tsai M, Geissler EN, Zsebo KM, Galli SJ 1992. The rat c-kit ligand, stem cell factor, induces c-kit receptordependent mouse mast cell activation in vivo. Evidence that signaling through the c-kit receptor can induce expression of cellular function. J Exp Med 175: 245-255.

Zsebo KM, Williams DA, Geissler EN, Broudy VC, Martin FH, Atkins HL, Hsu RY, Birkett NC, Okino KH, Murdock DC, Jacobsen FW, Langley KE, Smith KA, Takeishi T, Cattanach BM, Galli SJ, Suggs SV 1990. Stem cell factor is encoded at the Sl locus of the mouse and is the ligand for the c-kit tyrosine kinase receptor. Cell 63: 213-224. 
